\title{
Research on the Relevance between Land Policy and Property Price of China
}

\author{
HengTian \\ Tianjin University of Finance and Economics, Tianjin, 300222, China
}

Key Words: land market, the real-estate industry, macro-control

\begin{abstract}
Land is the fountainhead of the development of the real-estate market. The fluctuation and adjustment of the land market, with no doubt, will affect the price, the total supply and the supply structure of the real-estate market directly, and thus have an impact on the macroeconomic operation. A healthy land market will promote not only the smooth and healthy development of the property market, but also the normal operation of the national economy. In this paper, the author clarifies the various mechanisms of land policy to the real estate market, which will provide effective scientific basis for drafting policies to regulate the real-estate industry, as well as provide a reference for decision-making.
\end{abstract}

\section{Introduction}

As the dominant industry promoting China's economy and social development, real estate industry, which is closely related with a dozen of industries, such as financial, construction, non-metallic mineral manufacturing and chemical industries,is a great driving force for the whole industrial chain. Consequently, the fluctuation of it not only has a significant impact on its associated industries, but also affects the stable and concerted development of macro economy, plunging the national economy from normal tracks. The rapid development or real estate market is the core reason why China chooses investment-driven growth pattern,which explains the skyrocketing property price form a perspective of governmental behavior pattern. Land is the source of progress and one of the most important production elements of real estate market, therefore, the fluctuation and adjustment of land market have a direct influence on the price, gross supply and supply structure of real estate market, affecting the operation of macro economy.

Real estate market is not only viewed as production element and physical asset, it also plays a role of virtual asset in consideration of its capitalized pricing mode. With the rapid development of real estate market, housing price has been on a rise: in the second half of 2016, prices of newly built homes in 70 large and medium-size Chinese cities rose $8.92 \%$. China's land transaction price has also increased: in the second half of 2016, real estate development investment and land purchase cost rose $2.32 \%$. Since 2002, China has issued regulations that real estate developers could get land only by public land leasing, which indicates that China's land market has officially introduced competition mechanism, and marks the beginning of the marketing reform of land use. According to the latest annual communique of land and resources, the area of transferred land by public land leasing occupied $92.3 \%$ of the total. The institution of land acquisition has been transferred from previous administrative allocation and approved selling to current public land leasing, and the marketing reform of land doubtlessly fuels a rapid growth in land price. Since 2004, Chinese government has considered land policy as the third important mean of macro-control policy. To sum up, healthy land market not only accelerates the stable and sound development of real estate market, but also serves as a crucial role in the normal operation of national economy.

However, on account of the lack of experience that governments apply land policy to macro-control policy in China and abroad, problems, such as what role land policy plays in regulatory process and how it operates, need to be studied from both theoretical and practical level. Consequently, identifying the effects land policy exerts on real estate market is in top priority, which not only provides scientific basis for the effective formulation of land policy aiming at 
regulating real estate market, but also provide reference for governmental relevant decision-making.

\section{Theoretical analysis}

In recent years, the real estate market has developed excessively in China.In order to ensure the smooth and healthy development of the real estate market and maintain the smooth operation of the national economy, the land policy has become the third effective means of macro-control after the fiscal policy and monetary policy. Since 2004, the land market has been regulated from four aspects: land-supply levels,land prices, modes of land supply and the structure of land supply.

First of all, the land-supply levels, land prices and the structure of land supply affect the allocation of land which is the most important element in the real estate market directly. Zhou Jingkui (2006) conducted a study on the transmission mechanism of the land-supply levels and property prices, and he proposed a model that land size-land prices-property prices to analyse the relationship between the land-supply levels and property prices.As the government monopolized the land management market, the amount of land supply affects the prices of land transactions straightforward.

A number of research achievements related to the relationship between land prices and property prices mainly focused that "Does the high property prices lead to the high land prices or the high land prices drive the high property prices". The author believes that, due to the huge demand for real estate (including home-user demand, the demand for improving the living environment and speculative demand), the escalating property prices will lead to the rise of land prices inevitably. However the land prices is a part of the price of real estate, the land prices will also play a corresponding role in the process of the rapid development of the real estate market.

From the classifications of land uses, the inappropriate plan of land use which allocate the proportion of the industrial land, the commercial land and the residential land will raise the prices of another two types of land uses. For example, the government frequently increase the quantity of industrial and commercial land and appeal to enterprises and investments to boost the development of local economy, but this kind of behavior will reduce the supply of the residential land and raise the property prices eventually. From the structure of the residential land, different grades of housing structure can also lead to the rise of property prices. For example, the unreasonable land supply proportion of villas, high-end residential, affordable housing and ordinary residential suburb will obviously raise the real estate prices in other markets.

In addition, the price in the land transaction will also be affected by the the decision-making of land supply. From the year 2002, Chinese government has enacted a new policy related to the type in land transaction — the land use of commerce, tourism, entertainment and residence must be purchased through bidding, auction and listing. The System of Land Tender, Auction and Listing improves the efficiency of land use obviously, restore the real price of the land and played the important role in market mechanism. However, due to the vicious competition of some greedy property developers, the prices of property also raised in a certain degree. Then, we use the economic interpretation proposed by Shan Zhipeng (2013) for further analysis:

(A)The government is the only supplier of land, and the land demand side and the land supply side are all rational people;

(B)Compared with the price through bidding, auction and listing, one of selling by agreement is more lower than that;

(C) The price under the System of Land Tender, Auction and Listingis the equilibrium price of the perfect competition market;

(D)Without considering the impact of other factors.

\section{Empirical analysis}

Vector auto-regressive (VAR) is a model based on the statistical properties of data.It constructs a model which regards every endogenous variable as a function of the lag value of all the variables in the system. AS a result, the univariate auto-regressive model could be extended to a Vector 
regression model composed of multivariate time series variables-frequently used for researching interrelationship of macroeconomic variables. Moreover, the impulse response function is used to analyze the dynamic effects of the model under a certain impact; and the variance decomposition is used to analyze the contribution of each shock to the endogenous variables. Therefore, we set the model to:

$$
y_{t}=c+\sum_{i=1}^{p} A_{i} y_{t-1}+\varepsilon_{t}
$$

Where y represents the column vector consisting of the real estate price, the land price and the land supply area, and $\mathrm{b}$ represents the residual column vector.

In this paper, the monthly data is from January 2003 to December 2016, land prices is represented by the ratio of total land price and land area. Due to the seasonal fluctuations in each period,the author deal with data by seasonal adjustment,then process data with logarithm.

\section{Unit root test}

Considering the non-stationary of data of each period,each variable should be tested by unit root,in order to avoid the phenomenon of pseudo-regression. The results are as follows:

Table1: Results of unit root test

\begin{tabular}{c|c|c|c|c|c|c|c}
\hline Variables & Sign & ADF & $1 \%$ & $5 \%$ & $10 \%$ & P & $\begin{array}{c}\text { Stationary } \\
\text { of data }\end{array}$ \\
\hline $\begin{array}{c}\text { Property } \\
\text { Prices }\end{array}$ & LNHP & -14.82976 & -3.470179 & -2.878937 & -2.576124 & 0.0000 & stationary \\
$\begin{array}{c}\text { Land Prices } \\
\text { Land Supply } \\
\text { Capacity }\end{array}$ & LNLP & -17.77165 & -3.470179 & -2.878937 & -2.576124 & 0.0000 & stationary \\
& -20.69252 & -3.470179 & -2.878937 & -2.576124 & 0.0000 & stationary
\end{tabular}

As can be concluded from table 1:LNHP,LNLP and LNLA are stationary after the first-order difference, through the unit root test of LNHP,LNLP and LNLA.

\section{Co-integration test}

The above results show that the first order difference of the three variables are stationary sequences, and then we make a co-integration test to judge whether there is a long-term stable relationship between the three variables. The results of co integration test are shown in Table 3 .

Table 2 shows that there is a long-term stable co-integration relationship between LNHP,LNLP and LNLA at the 5\% confidence level.

Table 2: Results of Co-integration Test

\begin{tabular}{c|c|c|c|c}
\hline $\begin{array}{c}\text { Hypothesized } \\
\text { No. of CE(s) }\end{array}$ & Eigenvalue & $\begin{array}{c}\text { Trace } \\
\text { Statistic }\end{array}$ & $\begin{array}{c}0.05 \text { Critical } \\
\text { Value }\end{array}$ & Prob.** \\
\hline None $*$ & 0.195166 & 69.46024 & 42.91525 & 0.0000 \\
At most 1 & 0.153226 & 33.63554 & 25.87211 & 0.0044 \\
At most 2 & 0.036835 & 6.192554 & 12.51798 & 0.4362
\end{tabular}

\section{Granger causality test}

After confirming the long-term co-integration relationship between the above three variables,we make the Granger causality test to judge whether there is a causal relationship between the three variables. The result is as follows: 
Table 3: Results of the Granger causality test

\begin{tabular}{l|l|l|l}
\hline Null Hypothesis: & Obs & F-Statistic & Prob. \\
\hline LNHP does not Granger Cause LNLA & 166 & 2.43746 & 0.0906 \\
LNLA does not Granger Cause LNHP & & 0.05754 & 0.9441 \\
LNLP does not Granger Cause LNLA & \multirow{2}{*}{166} & 3.43678 & 0.0345 \\
LNLA does not Granger Cause LNLP & & 5.9754 & 0.0031 \\
LNLP does not Granger Cause LNHP & \multirow{2}{*}{166} & 2.75796 & 0.0664 \\
LNHP does not Granger Cause LNLP & & 11.1719 & 0.00003
\end{tabular}

From the results of the Granger test, at $10 \%$ confidence level,there is a two-way causality between LNHP and LHLP; there is a two-way causality between LNLP and LNLA; LNHP is the Grainger reason for LNLA, while the LNLA is not the Granger reasons for LNHP.

\section{Impulse response function analysis}

In the VAR model, the impulse response function is often used to analyze the dynamic effect of a system when the error term changes, or when the model is subjected to some impact.

\section{Impulse response analysis of property prices}

From the VAR model of the property prices affected by land supply and land prices, we can conclude the land price has a positive impact on the property price in the 1-4 periods, which reaches the maximum influence in the fourth period.Then the influence stables in the positive state, which indicates that the land price has a positive impact on the property price in the long-term.It is also exactly in accordance with the view__ land prices as the element of the property price drives the property prices upwards to a certain degree.

The land supply has a negative impact on the property price in the 1-4 periods, which reaches the maximum influence in the fourth period.Then the influence stables in the negative state,indicating that land supply gives negative impact to the property price in the long-term.
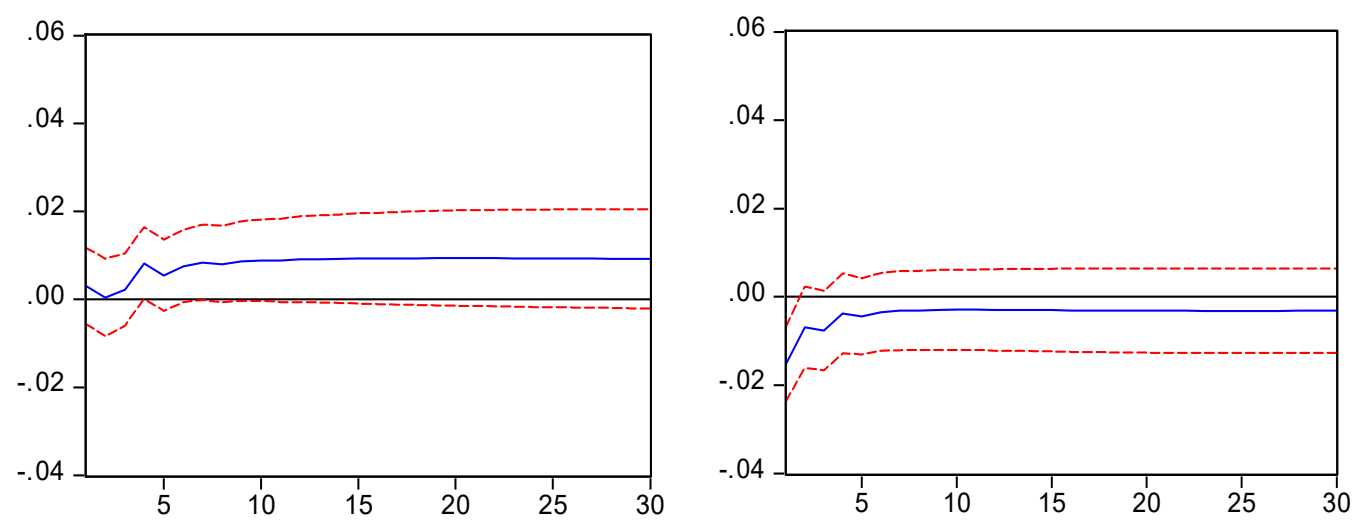

Impulse response analysis of land prices

From the VAR model of the land price impacted by the property price and land supply,it can be concluded that the property price plays a negative role in the land market in the 1-2 periods, which becomes positive effect since the third period.And the land price stables in positive state considering the influence of the property price.

This shows that although the land price exhibits a trend of irregular fluctuations in the short period of 1-2,the property price has a effectively affect on the land price in the long-term. 

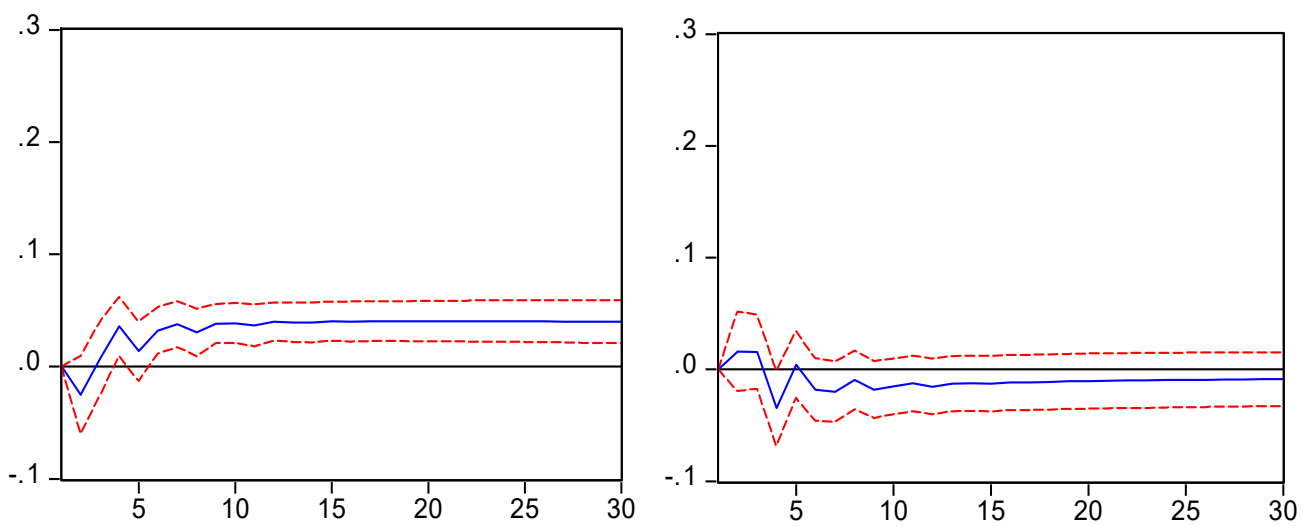

According to the VAR model of the land price impacted by the land supply,the land supply has a positive effect on the land price in the short-term, which may be due to the hoarding behavior and the vicious competition from property development facing the increasing of land supply.Rather,it is not difficult to draw that land supply has a negative effect on land price-mainly because the increasing supply in the land mark lead to the declining of prices according to the fundamental demand-supply market.

\section{Variance decomposition}

On the basis of the Variance decomposition,we can analyze the contribution from each structure impact to the endogenous variable, and to further evaluate the importance of different structural impacts. The result of the variance decomposition are as follows:

According to the figure, the property price is mainly affected by itself and the land supply in the short-term, and by itself and the land price in the long run. The contribution rate of the property prices itself remains at around $85 \%$; while thecontribution rate of land prices continued to rise from the first period,and then kept the level of about $15 \%$. Rather,the variance contribution rate of land supply area is maintained at a low level in the long run.

Land prices are mainly affected by themselves and the property prices. It can be found that,the variance contribution rate of land supply area is maintained at a low level both in the short and long term.In the long term, land prices mainly affected by itself and the property price,further,the variance contribution rate of the land price is decreasing; on thecontrary the variance contribution rate of the real estate price increases gradually and stables at about $20 \%$.
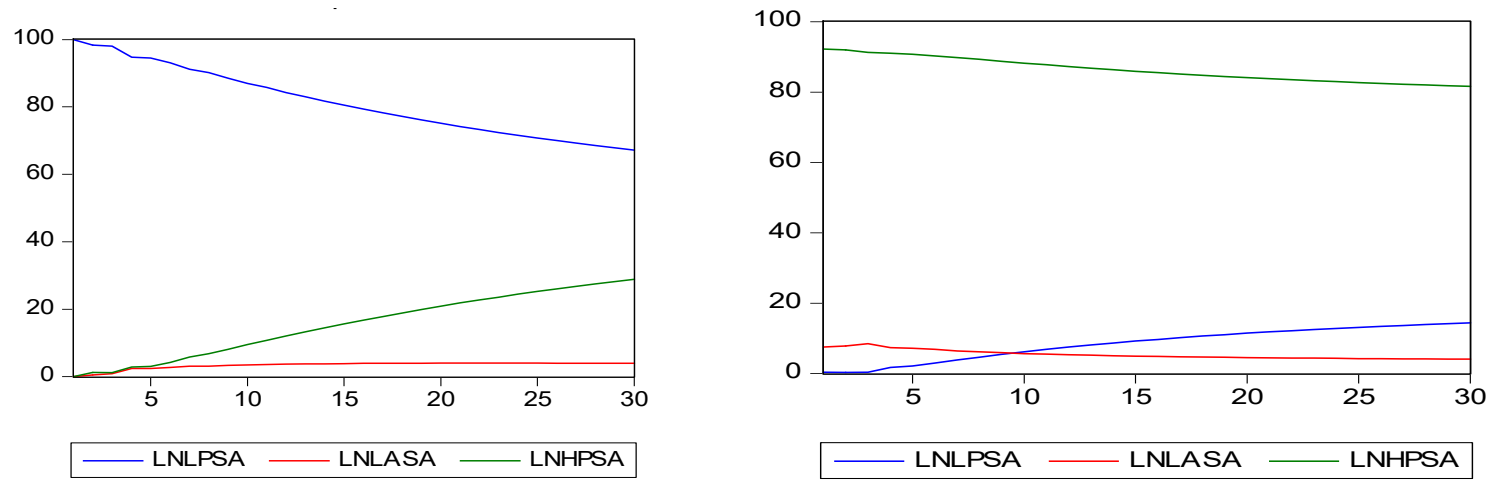

\section{Conclusion}

Land supply management refers to the adjustment to land utilization in real estate market. The gaps in land supply, land price and house price between cities of different ranks reflect the structural unbalance of land index distribution. Consequently, the reasonable management and operation of land market play a crucial role in the stable and healthy development of real estate market in China.

From a perspective of gross structure management, effective population-land approval pattern of land index should be established. After the examination of the amount of reserve land, ineffective and invalid land in different areas, the government should strictly evaluate land index according to the population permanent residences, keeping the reckless land sales of small cities within limits, 
improving their land utilization efficiency and establishing examination management system of it.

In view of land utilization structure management, the local governments ought to keep optimizing various land utilization structures, adjusting its proportion on the basis of scientific planning, distributing land according to population size, industrial structure and development mode, integrating the promotion in land utilization efficiency into their assessment criteria. Abandoning land, delaying development and violating development time limit should also be strictly supervised by law.

In consideration of regional coordinated development, local authorities should make concerted efforts, Developing distinctive small-medium cities and small towns around congested central cities, accelerating the process of transportation integration and social management integration. Besides, they should resolve low-priority functions of central cities and facilitate cooperative development of regional industrial division to drive population mobility and refrain the rigid demand of real estate market from solidifying in central cities.

In view of supply pattern, central government should emphasize the control of short term behavior pattern that local authorities benefit from land sales, applying different bidding methods to different types of land to improve current land remising system, substituting land utilization efficiency( including tax, employment and social benefit) and land utilization quality( including construction quality and cost-effectiveness) for price as the bargaining chips for land bidding. Meanwhile, central government should establish accountability mechanism to stabilize the commodity price and house price. The accountability mechanism could guarantee the consistent action of central and local government, which is an indispensable part.

Finally, when it comes to rural collective construction land entering the capital market, research on the institution of small property house and homestead listing should be conducted as soon as possible to avoid the risk of damaging rural collective economy and farmer interest.

\section{References}

[1] Michael J. Potepan, Explaining In termetropolitan Variation in Housing Prices, Rents and Land Prices.Real Estate Economics ,1996, 24(2), 219-245.

[2] Miller, N., S. Jones and S. Roulac, In Defense of the Land Residual Theory. Journal of Real Estate Research, 1995, 10, 203-216.

[3] Deng F F. Public Land Leasing and the Changing Roles of Local Government in Urban China [J]. The Annals of Regional Science, 2005, 39(5): 353-373.

[4] Hong Y H. Transaction Costs of Allocating Increased Land Value under Public Leasehold Systems: Hong Kong [J]. Urban Studies, 1998, 9( 1) : 1577 -1595.

[5] Tian, L. M, W. J. Government Intervention in City Development of China: A Tool of Land Supply[J]. Land UsePolicy, 2009, (26): 599-609. 